Nordic Concrete Research - Publ. No. NCR 60 - ISSUE 1 / 2019 - Article 4, pp. 51-66

\begin{tabular}{|c|c|}
\hline$S$ sciendo & 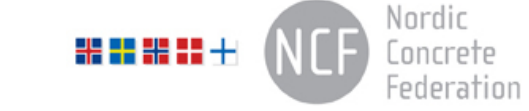 \\
\hline $\begin{array}{l}\text { (C) Article authors. This is an open access article distributed under } \\
\text { the Creative Commons Attribution-NonCommercial-NoDerivs } \\
\text { licens. (http://creaticecommons.org/licenses/by.nc-nd/3.0/). }\end{array}$ & $\begin{array}{l}\text { ISSN online } 2545-2819 \\
\text { ISSN print } \quad 0800-6377\end{array}$ \\
\hline DOI: $10.2478 /$ ncr-2019-0011 & $\begin{array}{r}\text { Received: April 1, } 2019 \\
\text { Revision received: June 21, } 2019 \\
\text { Accepted: June 25, } 2019\end{array}$ \\
\hline
\end{tabular}

\title{
Failure of Lightweight Aggregate Concrete in Compression under Stress Gradients
}

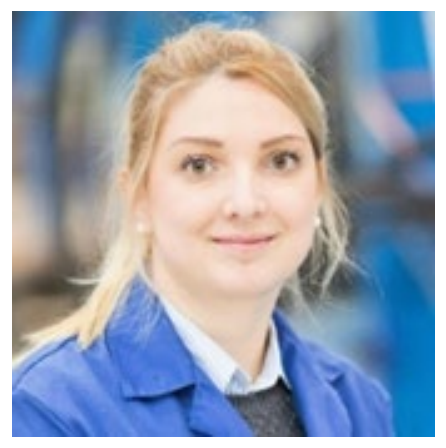

Jelena Zivkovic

M.Sc. PhD-candidate

Department of Structural Engineering

Faculty of Engineering Science

Norwegian University of Science and Technology

N-7491 Trondheim, Norway

e-mail: jelena.zivkovic@ntnu.no

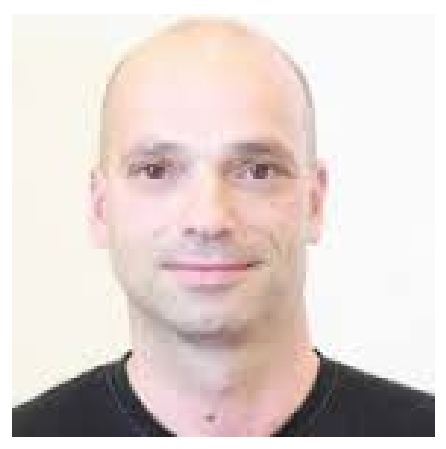

Jan Arve Øverli

$\mathrm{PhD}$, Professor

Department of Structural Engineering

Faculty of Engineering Science

Norwegian University of Science and Technology

N-7491 Trondheim, Norway

e-mail: jan.overli@ntnu.no

\begin{abstract}
The objective of this experiment is to investigate the behaviour of lightweight aggregate concrete (LWAC) under compression and with stress gradients. Experimental program contained three sets of LWAC which were used for production of 21 prisms. Lightweight aggregate argillite slate, called Stalite, from North Carolina had been used. The sets differed in using dry $(0.10 \%$ moisture content) or saturated (7.9\% moisture content) aggregate. The third set included a small amount of polyvinyl alcohol fibres (PVA). The geometry of the prisms were $100 \times 140 \times 480 \mathrm{~mm}$ (width $\times$ length $\times$ height). Prismatic samples were loaded centrically and eccentrically in compression.
\end{abstract}


From the achieved experimental results, it is visible that the lateral deformation of the most stressed fibre is counteracted by the less stressed fibres that confine compressive stress and increase strains. The obtained strain level was much higher than expected, especially for the third set of concrete samples with PVA fibres. Recorded strains in prisms test was in range from $3.08 \%$ to $6.82 \%$ ). In general, LWAC with Stalite showed ductile behaviour followed with very high strains. The third set of samples included a small amount of polyvinyl alcohol fibres $(0.5 \%$ of volume fractions) was even more ductile and non-brittle.

Key words: Lightweight Aggregate Concrete, Testing in Compression, Strain level, Centric and Eccentric Loading, Stress Gradients

1.

INTRODUCTION

1.1

General

This investigation is part of the ongoing research program "Durable advanced concrete structures (DaCS)". The part of this program is to investigate structural behaviour of lightweight aggregate concretes (LWAC), concretes with an oven dry density below $2000 \mathrm{~kg} / \mathrm{m}^{3}$. The use of lightweight aggregate concrete (LWAC) is limited as a mainstream construction material in structural applications. A reason for that is related to the steepness of the descending branch of the stressstrain curve in compression [1-3]. Material models for compressive failure of concrete are normally based on a uniaxial compressive stress-strain curve obtained from tests, where the main assumption is uniform deformation of the concrete specimens. This assumption is reasonable for the ascending branch of the stress-strain curve, while for the descending branch it is not realistic as it is always accompanied by significant lateral deformations. The lateral deformations are mainly caused by splitting cracks, which are formed and expand during the test. LWAC is characterized by more brittle post-peak material behaviour and uncontrolled crack propagation compared to normal weight concrete (NWC).

In order to describe more in detail, the compressive behaviour and to measure compressive strains, the effect of a stress gradient was introduced and varied in an experimental program. Stress gradients influence both the strength and the ductility [4]. Beam experiments tested in the DACSproject had shown that high strength LWAC with Stalite as aggregate obtained much higher compressive strain levels than expected [1]. The raw material mined by STALITE is an argillite slate located in a geological area known as the Tillery Formation in North Carolina. It is a thinly laminated, grey, fine-grained siltstone, composed of clastic (transported) rock fragments. The Tillery Formation is a complex system that must be selectively mined in order to separate the desirable product from the non-desirable to manufacture a high quality expanded slate aggregate. Raw material is latter expanded in a rotary kiln to produce porous structural lightweight aggregate. The cooled, expanded slate is later conveyed to the classification area, where it is crushed and screened into different size fractions. After crushing, the different size fractions are stored in separate silos until they are blended into standard or custom gradation blends. Due to the higher material strength of STALITE slate aggregate, higher strength concretes can be achieved with lower cement contents allowing for more economical concrete mixes [5].

Three sets of test specimens were produced using lightweight aggregate Stalite fraction size $1 / 2$ inch $(12.7 \mathrm{~mm})$, from the same batch, where the water content in aggregate varied between $0.1 \%$ 
and $7.9 \%$. The present experimental program included three LWACs for the production of 21 prisms. From each concrete, a total of $2 \times 9+1 \times 3$ prismsand small samples (i.e. cubes and cylinders) were produced. The third set of samples included a small amount of polyvinyl alcohol fibres $(0.5 \%$ of volume fractions). The geometry of the prisms were $100 \times 140 \times 480 \mathrm{~mm}$ (width $\times$ length $\times$ height). All samples were loaded both, centrically and eccentrically in compression.

The experimental setup of the prisms and the eccentricities were the same as in an earlier experiment and are therefore comparable [4]. The earlier studies looked at the lightweight concrete Liapor 8 and different types of normal weight concrete.

EXPERIMENTAL PROGRAMME

\section{1}

\section{Test specimens}

The experimental program consisted of 21 prisms, dimensions $100 \times 140 \times 480 \mathrm{~mm}$ (width $\times$ length $\times$ height), of plain LWAC which were loaded both centrically and eccentrically in compression. This study looks at the differences of using dry-DLWAC $(0.10 \%$ moisture content $)$ or saturated - WLWAC (7.9\% moisture content) aggregate and the influence of adding $0.5 \%$ at volume fractions of polyvinyl alcohol fibres - FLWAC. In FLWAC the fibres were combined with the saturated aggregate concrete. The main test variables were the moisture of aggregate and the eccentricity of the loading. For each investigated combination, there were tested 3 samples. The complete test programme is shown in the Table 1.

Table 1-Test program for centrically and eccentrically loaded specimens

\begin{tabular}{|c|c|c|c|c|c|}
\hline \multirow{2}{*}{$\begin{array}{l}\text { Prism } \\
\text { No. }\end{array}$} & \multirow{2}{*}{ Type of concrete } & \multirow{2}{*}{$\begin{array}{c}\text { Aggregate } \\
\text { moisture } \\
{[\%]}\end{array}$} & \multicolumn{3}{|c|}{ Eccentricity / Number of the specimens } \\
\hline & & & $e=0$ & $\begin{aligned} e=h / 18(140 / 18 \\
=7.8 \mathrm{~mm})\end{aligned}$ & $\begin{aligned} e & =h / 6(140 / 6 \\
& =23.3 \mathrm{~mm})\end{aligned}$ \\
\hline $\begin{array}{l}\text { D1-3 } \\
\text { D4-6 } \\
\text { D7-9 }\end{array}$ & DLWAC & 0.1 & 3 & 3 & 3 \\
\hline $\begin{array}{l}\text { W1-3 } \\
\text { W4-6 } \\
\text { W7-9 }\end{array}$ & WLWAC & 7.9 & 3 & 3 & 3 \\
\hline $\begin{array}{l}\text { F1 } \\
\text { F2 } \\
\text { F3 }\end{array}$ & FLWAC & 7.9 & 1 & 1 & 1 \\
\hline
\end{tabular}

All prisms had the same geometry that was limited due to capacity of the actuator. The geometry and forms for the prisms are shown in Figure 1. All the specimens were cast vertically in three layers. Each layer was compacted first by stamping by hand and, when the form was filled, by additional compaction using an internal vibrator. The prisms were unmoulded 24 hours after casting and immediately stored in water with the intention of preserving their natural content of moisture to the largest possible extent. The specimens were afterwards stored in the laboratory in water, at the temperature of approximately $20^{\circ} \mathrm{C}$. The bottom of the specimens were prepared for testing by grinding and top of the specimens by sawing (see Figure 1.) and grinding at an age of 28 days. 

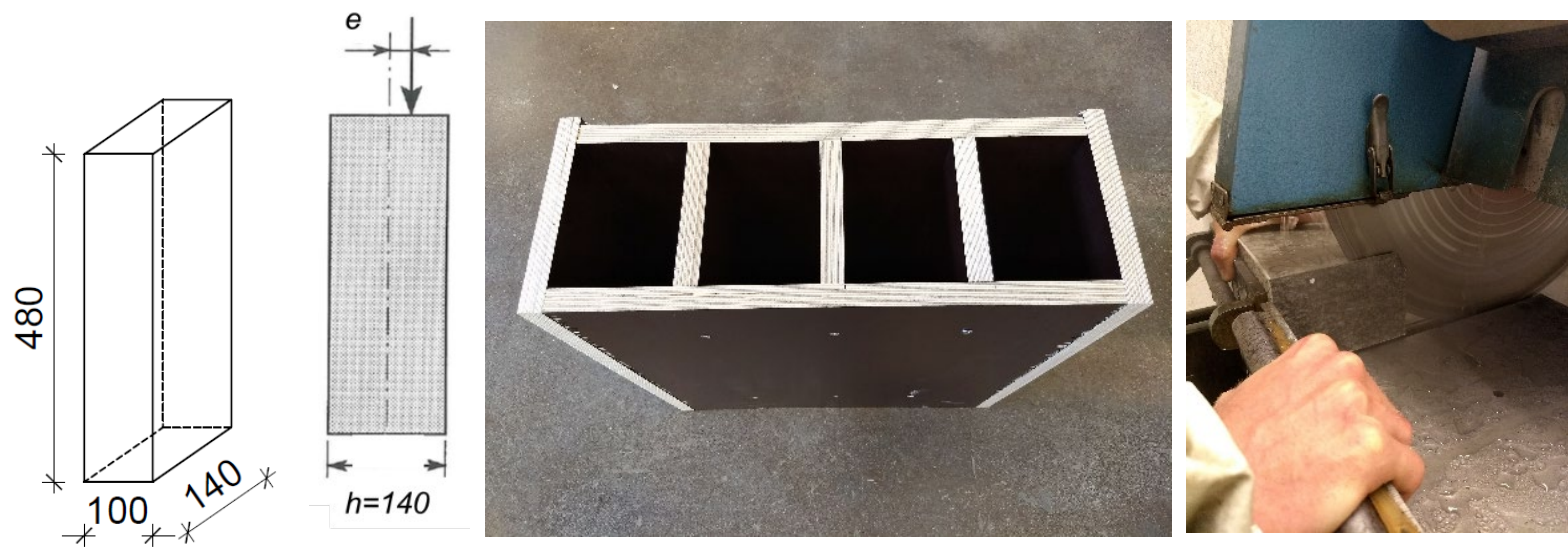

Figure 1 - Geometry of the prisms (left), Forms for the prisms (centre), Preparation of the prisms (right).

Two days before the testing prisms were taken out from water and prepared for instrumentation. Two sides of the prisms were painted white and highlighted with a black marker for digital correlation method. The strain gauges and Linear Variable Differential Transformers were attached at the two other sides. The test age of the prisms varied from 32 to 60 days.

To establish the mechanical properties of each LWAC, cubes (with dimensions $100 \times 100 \times 100$ $\mathrm{mm})$, cylinders $(\varnothing 100 \times 200 \mathrm{~mm})$ and small beams $(100 \times 100 \times 1200 \mathrm{~mm})$ were cast to find the stressstrain diagram, the compressive strength for cube and cylinder [6] the tensile strength [7], Young's module of elasticity [8,9], and the fracture energy [10]. All these small specimens were demoulded after 24 hours and kept in water until the testing day. In order to follow material characteristics compression tests on cubes and cylinders were carried out simultaneously with the prisms testing. All the prisms and small samples, cubes and cylinders, were cast from the same concrete batch.

\section{2}

\section{Material and mix properties}

The concrete mixture for each mix DLWAC, WLWAC and FLWAC was prepared from one batch of the aggregate with varying moisture of the aggregate from $0.1 \%$ (DLWAC) to $7.9 \%$ (WLWAC and FLWAC). The lightweight aggregate was $1 / 2 "(12.7 \mathrm{~mm})$ fraction from Stalite [11]. The moisture content and the absorbed water in the Stalite were measured to be able to design the concrete mix [12]. The moisture content varied from $0.1 \%$ to $7.9 \%$, while the absorption for this batch was stable and after 24 hours and 100 hours was $6.58 \%$ and $7.72 \%$, respectively. Table 2 gives the concrete mixtures. The mixing was done using two laboratory mixers with capacity of 250 liters and 50 liters. Two different mixing procedures were used. First procedure, called dry, was used for dry-DLWAC mixture, where all dry particles (cement, silica fume and sand) were placed in mixer and mixed for approximately 1 minute. Mixing was constant and aggregate Stalite was added to the rest of dry particles and mixed for $1 \mathrm{~min}$ more. Water and superplasticizer were continuously added and adjusted during mixing, until the desired workability of the concrete was achieved. Second procedure, called wet, was used for the wet-WLWAC and fibers-FLWAC mixtures. In the mixer first dry particles cement, silica fume and sand were added and mixed for approximately 30 seconds. Later approximately $70 \%$ of water and superplasticizer were added and after 1.5 minute, nice mortar was made. With continuously mixing presaturated aggregate Stalite were added and at the end rest of water and superplasticizer. After 2 minutes, resting and observation of the mixture and workability, additional water were added and superplasticizer until the desired workability of the concrete was achieved. 
Nordic Concrete Research - Publ. No. NCR 60 - ISSUE 1 / 2019 - Article 4, pp. 51-66

Table 2-Concrete mixtures for DLWAC, WLWAC and FLWAC

\begin{tabular}{cccc}
\hline Constituent weight (1000 liters) & $\begin{array}{c}\text { DLWAC } \\
\text { Weight } \\
{\left[\mathrm{kg} / \mathrm{m}^{3}\right]}\end{array}$ & $\begin{array}{c}\text { WLWAC } \\
\text { Weight }\left[\mathrm{kg} / \mathrm{m}^{3}\right]\end{array}$ & $\begin{array}{c}\text { FLWAC } \\
\text { Weight [kg/m }\end{array}$ \\
\hline Moisture of the aggregate [\%] & 0.1 & 7.9 & 7.9 \\
\hline Cement ( Norcem Anlegg FA) & 442.2 & 440.3 & 397.5 \\
Silica fume (Elkem Microsilica) & 23.3 & 23.2 & 20.9 \\
Water (free) & 146 & 180.8 & 163.2 \\
Absorbed water in Stalite+sand (24 hours) & 6.1 & 38.8 & 35.9 \\
Water* (added in mixer) & 139.9 & 142 & 127.3 \\
Sand (Ramlo 0-2 mm) & 230 & 231 & 377.3 \\
Sand (Årdal (NSBR) 0-8 mm) & 536.8 & 539 & 531 \\
Aggregate (Stalite 1/2"(12.7mm)) & 515.4 & 517.5 & 493 \\
Superplasticiser (Mapei Dynamon SR-N) & 3.3 & 3.9 & 6.2 \\
Fibers (Kuralon PVA 8mm) & - & - & 6.5 \\
\hline Water*/cement ratio [w/c] & 0.32 & 0.32 & 0.32 \\
\hline
\end{tabular}

For fiber-FLWAC it was used the same wet mixing procedure with just one additional step. Polyvinyl alcohol fibers (PVA) were added first in nice mortar in order to provide good distribution of the fibers in the concrete. Later procedure was the same.

Polyvinyl alcohol fibres is mostly use to improve the inherent brittleness of cementitious materials and to control cracking. They have very little effect on the flexural strength and deflection capacity. The compressive capacity is slightly reduced while concrete surface of the elements become extremely ductile [13]. In this test the main concern was to deal with brittleness, explosive failure and to improve ductility of LWAC. Because of that PVA fibres were introduced in range $0.5 \%$ at volume fractions. PVA was type "Kuralon RSC15", $8 \mathrm{~mm}$ long with E-modul of $36 \mathrm{MPa}$ [14].

For all prepared concrete mixtures, the fresh concrete characteristics like fresh density [15], air content [16] and slump [16] were followed. Results are given in Table 3.

Table 3 - Fresh concrete characteristics for DLWAC, WLWAC and FLWAC

\begin{tabular}{cccc}
\hline & DLWAC & WLWAC & FLWAC \\
\hline Fresh density $\left[\mathrm{kg} / \mathrm{m}^{3}\right]$ & 1989 & 2015 & 2011 \\
\hline Air content $[\%]$ & 2.5 & 1.9 & 2.5 \\
\hline Slump $[\mathrm{mm}]$ & 170 & 190 & 250 \\
\hline Matrix volume $\left[1 / \mathrm{m}^{3}\right]$ & 360 & 360 & 360 \\
\hline
\end{tabular}

\section{3}

Test Setup and the procedure

All the prisms were loaded in an electro-hydraulic, servo-controlled actuator with a maximum compressive load capacity of $1000 \mathrm{kN}$. Prisms were first preloaded with $100 \mathrm{kN}$ and later the load was constantly applied with a loading rate of $0.3 \mathrm{~mm} /$ minute until failure. This is displacement control test and load was applied centrically and eccentrically, which was provided by varying 
stress gradients. Test set and the stress diagrams for the applied eccentricities, based on the assumption of linear stress-strain relationship, are shown in Figure 2.

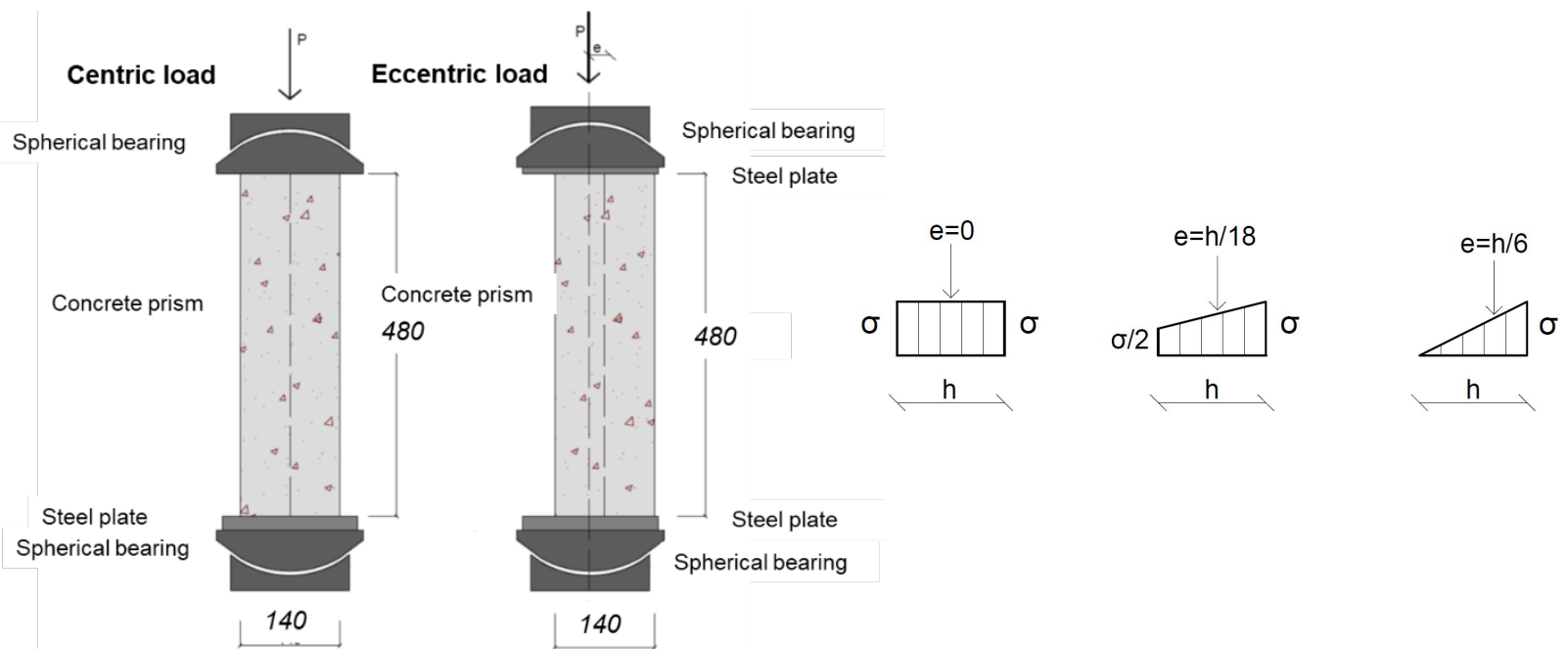

Figure 2 - Test setup for centrically and eccentrically loading. Stress distribution based upon linear theory for the different eccentricities (h is the height of the cross section).

The loading system was equipped with spherical ball bearings in direct connection to the top and the bottom surface of the prisms to ensure free rotation. The ball bearings were arranged in such a way that their rotation center lay on the surface of the specimens. Control lines were drawn on the contact plates of the bearings to ensured correct placement of the prisms. The contact surface between the ball and the concave ring of the bearings was lubricated prior to each test so as to reduce the friction at the sliding surface as much as possible [4]. Photos of the prism in the testing machine is shown in Figure 3.
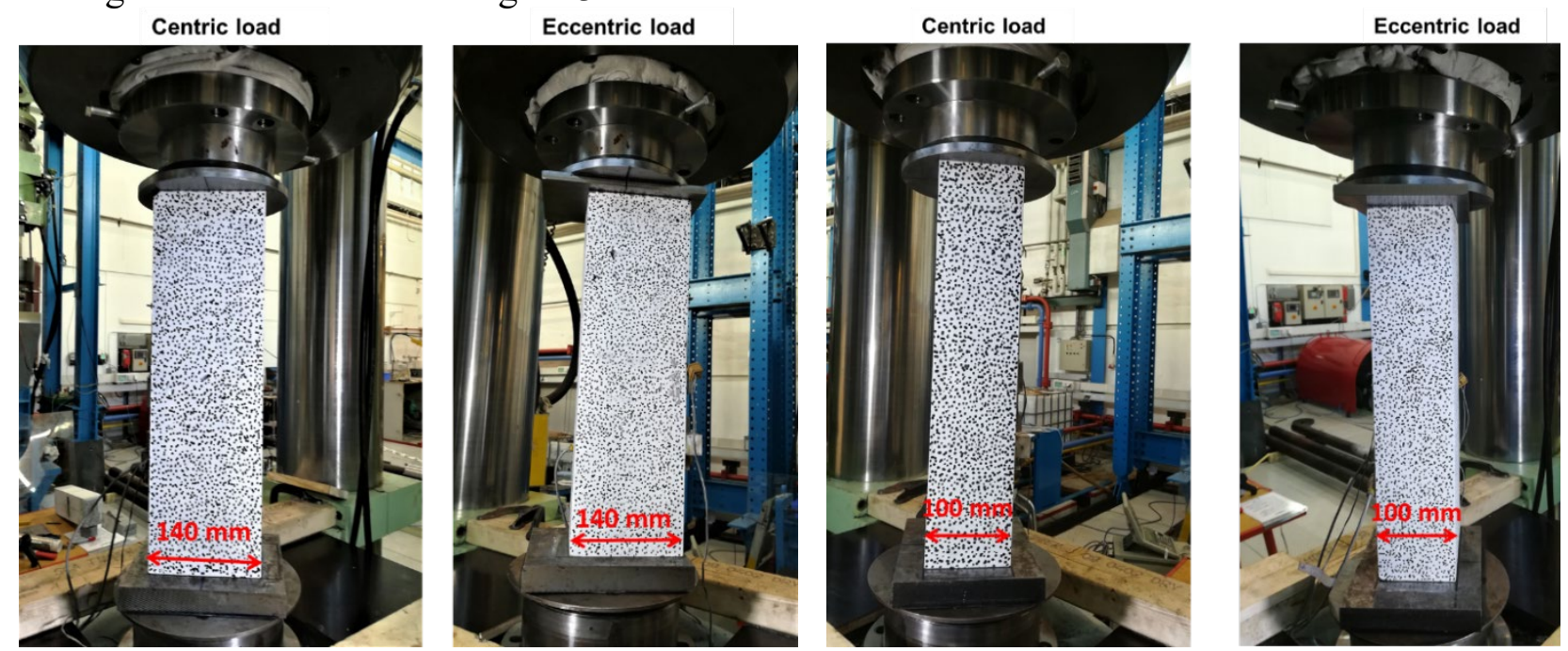

Figure 3 - Prism in the $1000 \mathrm{kN}$ testing machine. Wide side-140mm (left) and short side-100 mm (right).

\section{Instrumentation}

All the tested prisms were instrumented with the same measuring devices. Strain levels at the concrete area were recorded with strain gauges (SG) and Linear Variable Differential Transformers (LVDT) at two sides of the prism, called LVDT short and LVDT wide. On the other 
two sides, called DIC short and DIC wide, Digital Image Correlation (DIC) was used [17]. The location of the measuring devices is shown in Figure 4.

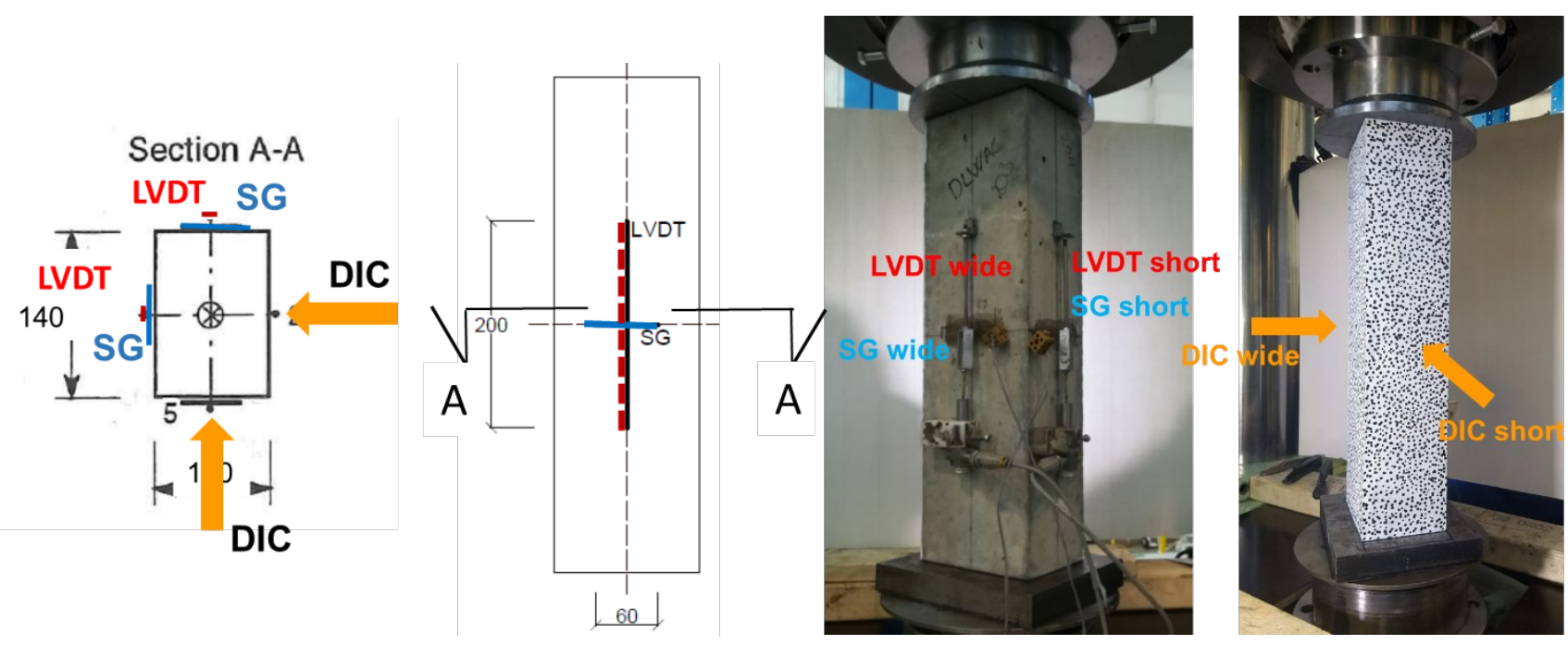

Figure 4 - Position of measuring devices for centric and eccentric loading.

The measuring length of the LVDTfor observation of longitudinal direction of middle section was $200 \mathrm{~mm}$. In addition, strain gauges with length $60 \mathrm{~mm}$ (type FLA-6-11-5L with gauge resistance of $119.5 \pm 0.5 \Omega$ ) were inserted in the middle section for observation of transversal direction. DIC was used on other two sides of the prism where the complete strain field was registered. In the eccentric load situation the DIC side was choosen as the onewith the maximum stress and where the highest strains were expected. For DIC was used set of two cameras and each were placed orthogonally in relation to the area of observation. That represent 2D DIC, see Figure 5.

All measuring devices (LVDTs and SGs) together with the load cell were connected to HBM eight channel spider to record the data. From here, data were sent to the computer using a specific software program, where the data were processedand stored in a text file. The deflection and load measurements were carried out as a control during the whole test. The output data were recorded by the data acquisition system. Pictures were taken at failure.

Since this was a compressive test and it is known that lightweight aggregate concrete can have very explosive failure special saftey precautions were requiredduring testing. Consequently, a plexiglass chamber around the concrete sample was used. It ensured that all parts of the concrete would stay inside of chamber when failure happened. 


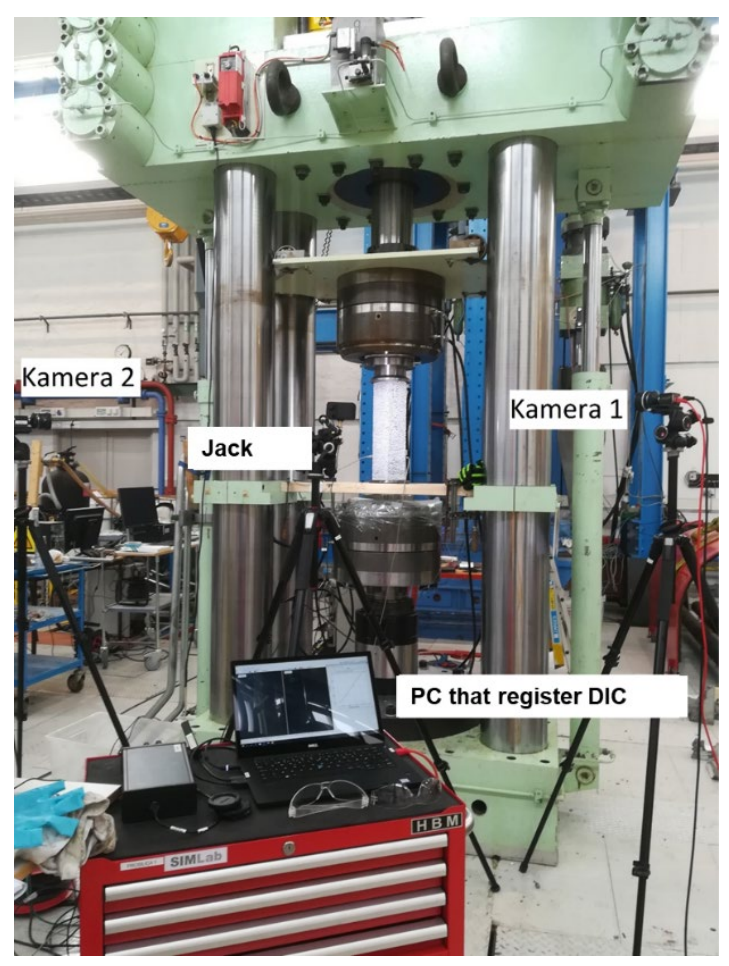

Figure 5 - Setup of the registration equipment.

3. EXPERIMENTAL RESULTS

\section{1}

Results for small specimens

Small specimens were tested after 28 days for determination of compressive strength, tensile strength and Young's modulus. Small beams for fracture energy for DLWAC were tested after 60 days and for WLWAC after 36 days. The fracture energy is determined on small $100 \times 100 \times 1200 \mathrm{~mm}$ beams according to SINTEF procedure [18]. This procedure is quite similar to the Hillerborg [10] proposed RILEM method. Small beams are just for $200 \mathrm{~mm}$ longer and notch is 0.4 instead of the 0.5 of the beam heights. Beams were first prenotched with notch debth $40 \mathrm{~mm}$ and tested in three-point bending test. Fracture energy is calculated when work or energy from the positive part of load-deformation curve observed during test is divided with fracture area. The aggregate type and content affect the result of fracture energy of concrete much stronger than the size of aggregates due to transition from the interfacial fracture to the trans-aggregate fracture. A brief summary of the small-scale test results is given in Table 4.

Table 4-Mechanical properties for DLWAC, WLWAC and FLWAC

\begin{tabular}{cccc} 
Saturated density $\rho_{\mathrm{cs}}\left[\mathrm{kg} / \mathrm{m}^{3}\right]$ & DLWAC & WLWAC & FLWAC \\
Oven dry density $\rho_{\mathrm{cv}}\left[\mathrm{kg} / \mathrm{m}^{3}\right]$ & 1997.9 & 2008.4 & 2019.2 \\
Compression strength for cube after 7 days $f_{\mathrm{lcm}, 7}\left[\mathrm{~N} / \mathrm{mm}^{2}\right]$ & 1979.9 & 1864.6 & 1899.5 \\
Compression strength for cube after 28 days $f_{\mathrm{lcm}, 28}\left[\mathrm{~N} / \mathrm{mm}^{2}\right]$ & 71.6 & 58.1 & 48.8 \\
Compression strength for cylinder after 28 days $f_{\mathrm{lcm}, 28}\left[\mathrm{~N} / \mathrm{mm}^{2}\right]$ & 67 & 77.5 & 71. \\
Tensile strength after 28 days $f_{\mathrm{lctm}, 28\left[\mathrm{~N} / \mathrm{mm}^{2}\right]}$ & 4.7 & 4.9 & 63.7 \\
Modulus of elasticity after 28 days $E_{\mathrm{lcm}, 28}\left[\mathrm{~N} / \mathrm{mm}^{2}\right]$ & 23653 & 21701 & 22549 \\
Fracture energy after 32 days $G_{\mathrm{F}}\left[\mathrm{Nm} / \mathrm{m}^{2}\right]$ & 79.7 & 82 & 74.9 \\
\hline
\end{tabular}


Concrete class measured from all small samples was LC65 and higher which represents a high strength lightweight concrete. The compressive failures of cubes and cylinders were very explosive which is typical for high strength and lightweight concrete [1].

\section{2}

\section{Results for prisms}

Figures 6 and 7 show the experimental results registered with LVDTs and SGs for the centrically and eccentrically loaded prisms.

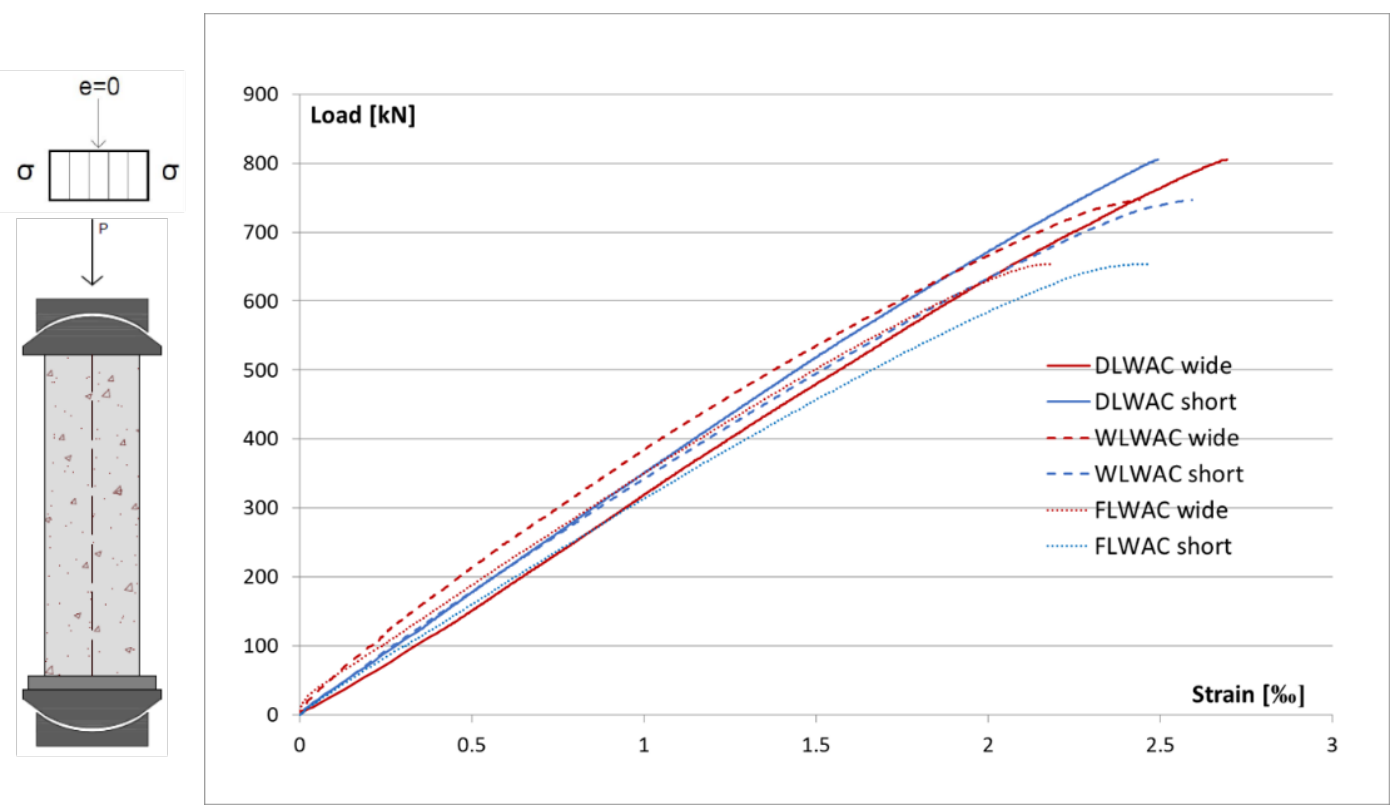

Figure 6 - Load-strain relationship for centric loading.

The load-strain relationship at centricity and eccentricity $h / 18$ and $h / 6$ are shown in Figure 6 and 7. The strains recorded with LVDTs represent lower strains that were registered during testing. For each loading case 3 prisms were tested. The curves are mean values from three tests, except FLWAC.

Table 5 - Test results

\begin{tabular}{|c|c|c|c|c|c|c|c|c|c|}
\hline $\begin{array}{l}\text { Prism } \\
\text { Nr. }\end{array}$ & $\begin{array}{l}\text { Type of } \\
\text { concrete }\end{array}$ & $\begin{array}{c}\text { Aggreg. } \\
\text { moist. } \\
{[\%]}\end{array}$ & $\begin{array}{l}f_{l, c, c u b e} \\
{[\mathrm{MPa}]}\end{array}$ & $\begin{array}{l}f_{l c, p r i s m} \\
{[\mathrm{MPa}]}\end{array}$ & $\begin{array}{c}\text { Eccentricity } \\
{[\mathrm{mm}]}\end{array}$ & $\begin{array}{l}P_{\max } \\
{[\mathrm{kN}]}\end{array}$ & $\begin{array}{l}P_{\text {calc }} \\
{[\mathrm{kN}]}\end{array}$ & $\begin{array}{c}\mathcal{E}_{c, L V D T} \\
{[\% \mathrm{o}]}\end{array}$ & $\begin{array}{l}\varepsilon_{c, D I C} \\
{[\% 0]}\end{array}$ \\
\hline $1-3$ & & & & & $\mathrm{e}=0$ & 804 & 763 & 2.69 & 3.12 \\
\hline $4-6$ & DLWAC & 0.1 & 77.9 & 57.5 & $e=7.77$ & 668 & 513 & 2.51 & 3.47 \\
\hline $7-9$ & & & & & $\mathrm{e}=23.33$ & 495 & 382 & 2.70 & 3.81 \\
\hline $1-3$ & & & & & $\mathrm{e}=0$ & 746 & 791 & 2.59 & 3.40 \\
\hline $4-6$ & WLWAC & 7.9 & 80.7 & 53.5 & $e=7.77$ & 648 & 531 & 2.19 & 3.69 \\
\hline $7-9$ & & & & & $\mathrm{e}=23.33$ & 541 & 395 & 2.96 & 4.53 \\
\hline 1 & & & & & $\mathrm{e}=0$ & 653 & 760 & 2.46 & 2.94 \\
\hline 2 & FLWAC & 7.9 & 77.6 & 46.7 & $e=7.77$ & 669.9 & 511 & 2.18 & 4.54 \\
\hline 3 & & & & & $\mathrm{e}=23.33$ & 577.8 & 380 & 3.38 & 6.82 \\
\hline
\end{tabular}

Where $f_{l \text { c,cube }}$ is compressive cube strength; $f_{l \text { c,prism }}$ is compressive prism strength $\left(P_{\text {max }}\right.$ divided with prism cross cestion $100 x 140 \mathrm{~mm}) ; P_{\max }-$ load level of maximum load; $P_{\text {calc }}-$ hand calculation of maximum load; $\mathcal{E}_{c, L V D T}-$ maximum concrete compressive strain recorded with LVDT; $\mathcal{E}_{c, D I C}$ - maximum concrete compressive strain recorded with DIC. 
In addition to this results Table 5 shows summary of all registered results. In the case of eccentrically loaded prisms, the compressive strain registered with LVDT presents the side that was less stressed, see Figure 7, while strains registered by DIC were at the most stressed side. In the case of centrically loaded prisms we can notice very good agreement between LVDTs (see Figure 6) and DIC measuring method. Average compressive strain levels recorded in all the prisms were between $3.08 \%$ and $6.82 \%$.
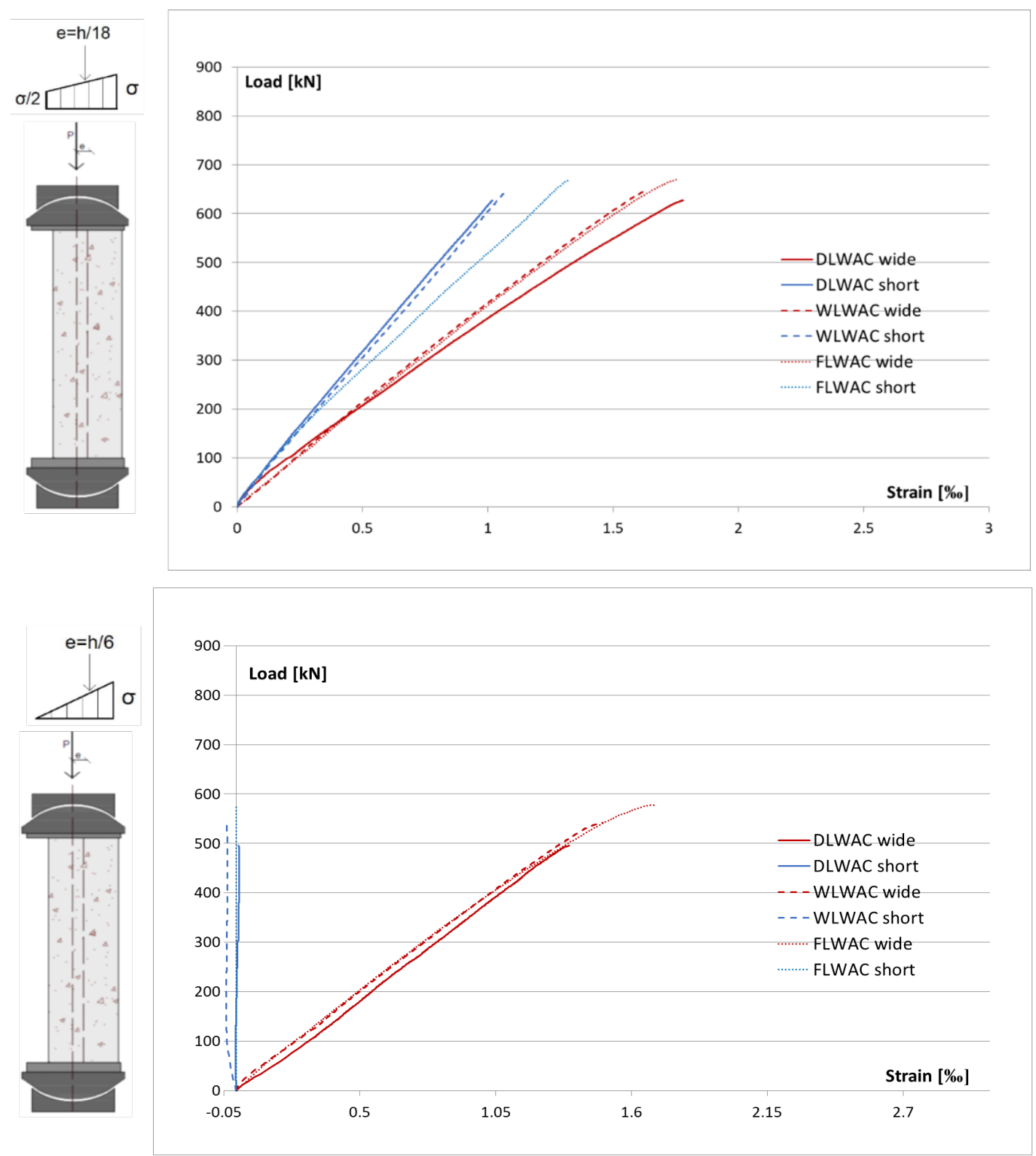

Figure 7 - Load-strain relationship at eccentricities $e=h / 18$ (top) and $e=h / 6$ (bottom).

3.3

\section{Failure mode and crack patterns of the prisms}

For a concrete specimen loaded in compression the fundamental failure mode is a combination of both axial splitting and sliding. However, the influence of each failure mode depends on concrete material factors such as concrete composition, type of aggregate and maximum aggregate size. 
For LWAC it is well known that the weakest part in matrix is aggregate itself and cracking line goes usually through the aggregate [4].

For centrically loaded prisms two types of failure happened: shear, sliding mode of failure (when micro-cracks coalesce to inclined localized shear bands) and longitudinal failure (axial splitting happened when a critical lateral deformation is exceeded), see Figure 8.

At eccentrically loaded prisms longitudinal failure occurred, opening of longitudinal tensile cracks led to the final failure, cracks proceeded within the damage zone. The typical mode of failure for the eccentrically loaded prisms is illustrated in Figure 8. For all samples, the breaking length $l_{b}$ and breaking depth $d_{b}$ of the fracture were recorded. Table 6 shows the fracture size. I final fase the centrally loaded prisms had longitudinal breaks that went in center of the sample and therefore it was not possible to measure the breaking length $\mathrm{lb}$ and breaking depth $\mathrm{db}$ of the fracture.
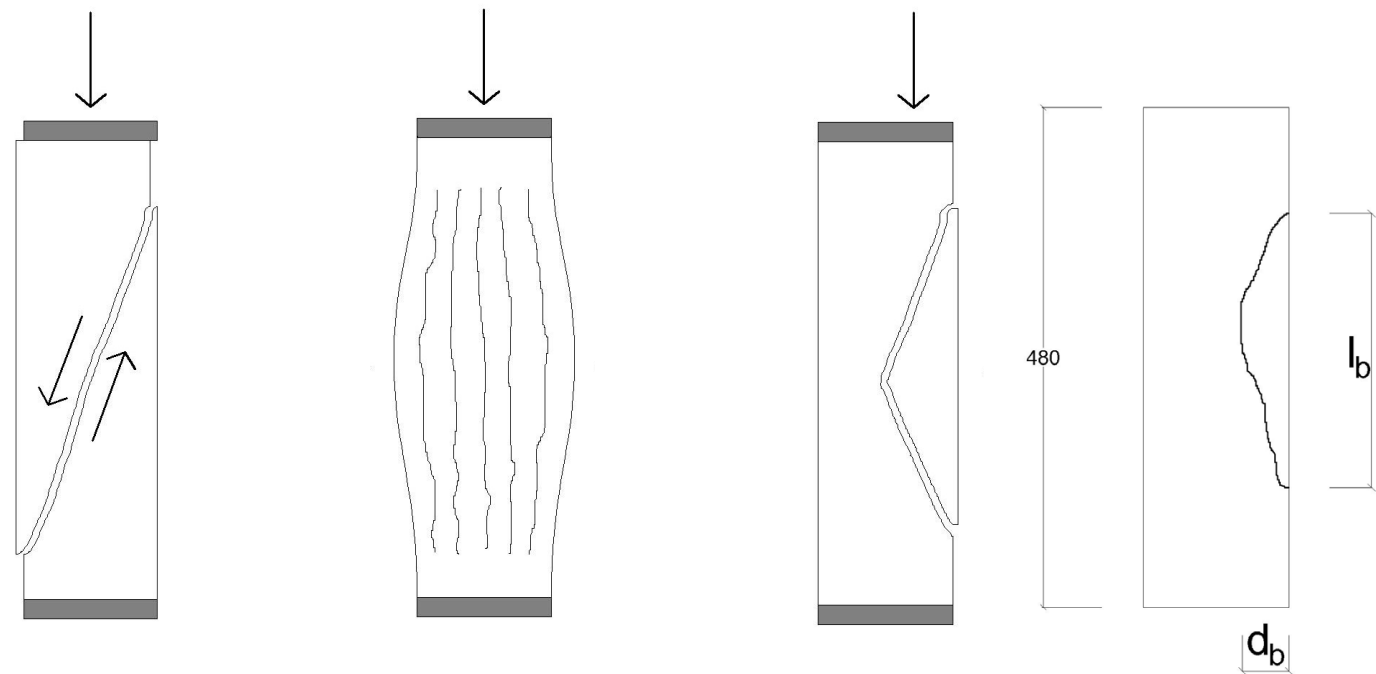

Figure 8 - Sketch of oblique shear fracture (left), longitudinal break (centre) and longitudinal tensile break at eccentric load (right). Typical mode of failure for the eccentrically loaded prisms (right).

Table 6 - Fracture size for eccentrically loaded prisms for DLWAC, WLWAC and FLWAC

\begin{tabular}{lccc}
\hline $\mathbf{e}=7.77 \mathbf{~ m m}$ & DLWAC & WLWAC & FLWAC \\
$l_{\mathrm{b}}[\mathrm{mm}]$ & 440 & 470 & 340 \\
$d_{\mathrm{b}}[\mathrm{mm}]$ & 110 & 110 & 60 \\
$l_{\mathrm{b}} / d_{\mathrm{b}}$ & 4 & 4.3 & 5.6 \\
$\mathbf{e}=\mathbf{2 3 . 3 3} \mathbf{~ m m}$ & DLWAC & WLWAC & FLWAC \\
$l_{\mathrm{b}}[\mathrm{mm}]$ & 370 & 410 & 290 \\
$d_{\mathrm{b}}[\mathrm{mm}]$ & 40 & 280 & 50 \\
$l_{\mathrm{b}} / d_{\mathrm{b}}$ & 9.2 & 5.1 & 5.8 \\
\hline
\end{tabular}




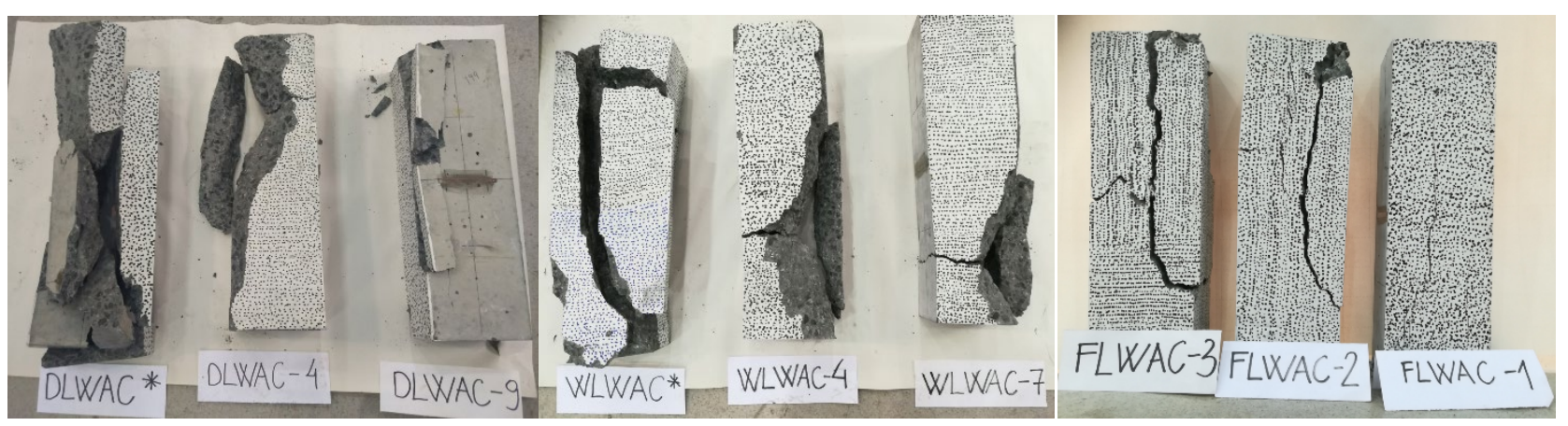

Figure 9 - Cracking pattern for centrically and eccentrically $h / 18$ and $h / 6$ loaded samples.

Crack propagation depended on the loading conditions. Prisms subjected to centrically loading cracked from the centre of the sample and experienced large cracks and the lowest ultimate compressive strain was registered. Prisms that were loaded eccentrically only cracked at the most stressed part with higher strains. Prisms that were loaded under larger eccentricity experienced just small cracking, see Figure 9.

Through qualitative visual inspection of the fracture, it was discovered that in the concrete with dry Stalite, the fractures both penetrated and travelled around the aggregate particles (approximately 60\% aggregate cracked), while in the concrete with saturated Stalite, the fracture to a much larger degree only penetrated the particles (almost $95 \%$ aggregate cracked) The concrete with the saturated Stalite had the most explosive fractures. By introducing a small amount of fibers $(0,5 \%$ of the cement mass) the concrete became significantly more ductile and did not have brittle behaviour. The fracture was not explosive, and the prisms kept together afterwards. In general measured breaking length and depth were significantly smaller for FLAC thatn for DLWAC and WLWAC.

\section{4.}

\section{DISCUSSION AND CONCLUSION}

A stress gradient test has been used to investigate strains and ductility. The test was done by loading prisms centrically or with two different eccentricities. The proportions of the prisms and eccentricities were the same as in an earlier experiment and are therefore comparable. This study investigates differences using dry $(0.10 \%$ moisture content $)$ or saturated ( $7.9 \%$ moisture content) aggregate Stalite, and the effect of polyvinyl alcohol fibres on the compressive behaviour of LWAC. Crack propagation depended on the loading conditions. Prisms subjected to centrically loading experienced large cracks and the lowest ultimate compressive strain, while prisms loaded eccentrically only cracked at the most stressed part with higher strains. By using DIC, detailed strain fields of the observed compressive zones have been recorded, see Figure 10.

From the achieved experimental results, it is visible that the lateral deformation of the most stressed fibre is counteracted by the less stressed fibres that confine compressive stress. Close to the peak load the lateral deformations near the free surface become pronounced. Finally, in the post-peak region two different fractures developed and ultimate strains increased. In general, larger eccentricity lead to increased strains (recorded strains in prisms test was in range from $3.08 \%$ to $6.82 \%$ ). 

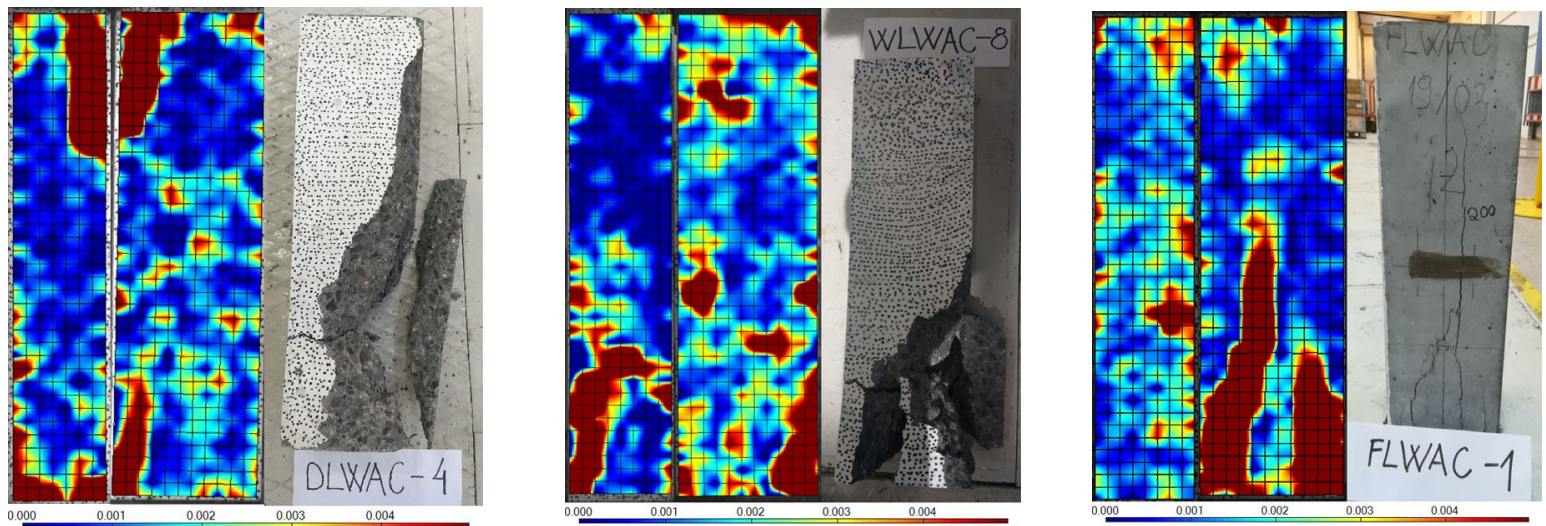

Figure 10 - Strain field for DLWAC (left), WLWAC (centre) and FLWAC (right) just before the final failure. Strain range from $0 \%$ o till 5\%.

In general, measuring devices were in a good agreement, but close to failure, larger strains and localization were measured using DIC, compared to the strain values measured with the SGs and LVDTs. The concrete with the water saturated aggregate had somewhat higher strains and ductility than the concrete with dry aggregate. Through qualitative visual inspection of the fracture, it was observed that the concrete with the saturated aggregate had the most explosive fractures. By introducing a small amount of fibers ( $0.5 \%$ of volume fractions) the concrete became significantly more ductile, with a maximum compressive strain of $6.82 \%$, and the fracture was not explosive. FLWAC samples in final faze kept together afterwards. Eurocode 2 [19] does not differ between lightweight concrete with different types of aggregates and underestimated the largest strains in this experiment by $75-88 \%$.

\section{1}

\section{Comparison with previous experimental work}

The experimental setup of the prisms and the eccentricities were the same as in an earlier experiment and are therefore comparable [4]. The earlier studies looked at the lightweight concrete Liapor 8 and different types of normal weight concrete. Table 7 compares new and old experiments. A ductility index $D$ is calculated as:

$$
D=\frac{\varepsilon_{c u}-\varepsilon_{e l}}{\varepsilon_{e l}} \cdot 100 \%
$$

where $\varepsilon_{c u}$ is maximum compressive strain and $\varepsilon_{e l}$ is strain corresponding to elastic state. In elastic state strains are reversible which recovers while applied stresses are being removed. Plastic strains yield in the specimen before reaching peak point (maximum compressive strains before failure). Elastic and plastic zone of specimen depends on the stiffness, brittleness and ductility of specimen. Concrete is more ductile if diference between elastic and maximum strain is larger. In that case ductility index $D$ is larger as well. Specimen having higher strength will lead to smaller strains and elastic portion in this case will be more. Concrete is a brittle material and it shows smaller value of strains before failure. 
Nordic Concrete Research - Publ. No. NCR 60 - ISSUE 1 / 2019 - Article 4, pp. 51-66

Table 7 - Comparison with experimental work from 1993 [2]

\begin{tabular}{|c|c|c|c|c|c|c|}
\hline $\begin{array}{l}\text { Type of } \\
\text { concrete }\end{array}$ & $\begin{array}{c}\text { Eccentricity } \\
{[\mathrm{mm}]}\end{array}$ & $\begin{array}{l}f_{l, p r i s m} \\
{[\mathrm{MPa}]}\end{array}$ & $\begin{array}{l}f_{l c, \text { cube }} \\
{[\mathrm{MPa}]}\end{array}$ & $\begin{array}{c}\mathcal{E}_{c u} \\
{[\% 0]}\end{array}$ & $\begin{array}{c}D_{, L V D T} \\
{[\%]}\end{array}$ & $\begin{array}{l}D_{, D I C} \\
{[\%]}\end{array}$ \\
\hline \multirow{3}{*}{ DLWAC } & $\mathrm{e}=0$ & \multirow{3}{*}{57.5} & \multirow{3}{*}{77.9} & 3.12 & \multirow{3}{*}{11.2} & \multirow{3}{*}{13.3} \\
\hline & $e=7.77$ & & & 3.47 & & \\
\hline & $\mathrm{e}=23.33$ & & & 3.81 & & \\
\hline \multirow{3}{*}{ WLWAC } & $\mathrm{e}=0$ & \multirow{3}{*}{53.5} & \multirow{3}{*}{80.7} & 3.40 & \multirow{3}{*}{15.1} & \multirow{3}{*}{14.9} \\
\hline & $e=7.77$ & & & 3.69 & & \\
\hline & $\mathrm{e}=23.33$ & & & 4.53 & & \\
\hline \multirow{3}{*}{ FLWAC } & $\mathrm{e}=0$ & \multirow{3}{*}{46.7} & \multirow{3}{*}{77.6} & 2.94 & \multirow{3}{*}{37.2} & \multirow{3}{*}{37.6} \\
\hline & $e=7.77$ & & & 4.54 & & \\
\hline & $\mathrm{e}=23.33$ & & & 6.82 & & \\
\hline \multirow{3}{*}{ Liapor 8} & $\mathrm{e}=0$ & \multirow{3}{*}{86.8} & \multirow{3}{*}{93.8} & 3.12 & \multirow{3}{*}{9.6} & \\
\hline & $e=7.77$ & & & 3.41 & & \\
\hline & $e=23.33$ & & & 3.55 & & \\
\hline \multirow{3}{*}{$\begin{array}{l}\text { Gneiss/ } \\
\text { Granite }\end{array}$} & $\mathrm{e}=0$ & \multirow{3}{*}{81.4} & \multirow{3}{*}{104.1} & 2.61 & \multirow{3}{*}{14.5} & \\
\hline & $e=7.77$ & & & 2.97 & & \\
\hline & $\mathrm{e}=23.33$ & & & 3.16 & & \\
\hline \multirow{3}{*}{ Basalt } & $\mathrm{e}=0$ & \multirow{3}{*}{89.0} & \multirow{3}{*}{105.1} & 2.72 & \multirow{3}{*}{31.7} & \\
\hline & $\mathrm{e}=7.77$ & & & 3.31 & & \\
\hline & $\mathrm{e}=23.33$ & & & 3.45 & & \\
\hline \multirow{3}{*}{ Quartzite } & $\mathrm{e}=0$ & \multirow{3}{*}{86.5} & \multirow{3}{*}{106.7} & 2.47 & \multirow{3}{*}{14.8} & \\
\hline & $e=7.77$ & & & 2.81 & & \\
\hline & $e=23.33$ & & & 2.84 & & \\
\hline
\end{tabular}

Where $\overline{f_{c, p r i s m}}$ is compressive prism strength; $f_{l c, \text { cube }}$ is compressive cube strength; $\mathcal{E}_{c u}$ - maximum concrete compressive strain ; $D_{L V D T}$ - ductility index calculated from maximum concrete compressive strain recorded with LVDT; $D_{, D I C}-$ ductility index calculated from maximum concrete compressive strain recorded with DIC.

It is clear that LWAC with Stalite showed more ductile behaviour than LWAC with Liapor 8. Compared to normal density concretes the ductility is similar while registered strains are much higher. When adding just small amount of polyvinyl alcohol fibers, the ductility increase, ductility index is doubled.

The results from this experiment are promising for increased use of high strength lightweight aggregate concrete with Stalite as aggregate for concrete structures. High strains and ductility show that concrete with Stalite can be considered as a product in between lightweight aggregate concrete and normal weight concrete. It combines the ductility from normal weight concrete with the low density from lightweight aggregate concrete. In general, based on this experimental results the use of high strength concrete with Stalite as aggregate should be increased because of the favourable combination of high strength with low density.

5. ACKNOWLEDGEMENT

The work presented in this paper is part of ongoing PhD study in scope of the DACS project (Durable Advanced Concrete Solutions). The DACS partners are Kværner AS (project owner), Norwegian Research Council, Axion AS (Stalite), AF Gruppen Norge AS, Concrete Structures AS, Mapei AS, Multiconsult AS, NorBetong AS, Norcem AS, NPRA (Statens vegvesen), Norwegian University of Science and Technology (NTNU), SINTEF Byggforsk, Skanska Norge 
AS, Unicon AS and Veidekke Entreprenør AS. Jelena Zivkovic would like to express hers outmost gratitude to the supervisors and all the project partners for contributions and making this $\mathrm{PhD}$ study possible. J. Zivkovic would like to thank to Master students Aleksander Hammer and Håvard Lauvsland for the help during experimental work.

\section{REFERENCES}

1. Zivkovic J \& Øverli J A: "Ultimate compressive strain in lightweight aggregate concrete beams". Proceedings, $12^{\text {th }}$ fib International PhD Symposium in Civil Engineering, Prague, Czech Republic, August 2018, pp. 829-836.

2. Nedrelid H: "Towards a better understanding of the ultimate behavior of lightweight aggregate concrete in compression and bending". Bulletin No.123 (PhD Thesis), Norwegian University of Science and Technology, Department of Structural Engineering, Trondheim, Norway, 2012, 214 pp.

3. Øverli J A: "Towards a better understanding of the ultimate behavior of LWAC in compression and bending". Engineering Structures, No. 151, 2018, pp. 821-838.

4. Markeset G: "Failure of concrete under compressive strain gradients". Bulletin No.110 (PhD Thesis), Norwegian Institute of Technology, Department of Structural Engineering, University of Trondheim, Trondheim, Norway,1993, 168 pp.

5. Carolina Stalite Company: "Production of Stalite". Salisbury, North Carolina, USA available: https://www.stalite.com/production.

6. Standard Norge: "Testing hardened concrete - Compressive strength of test specimens". Part 3, NS-EN 12390-3:2009, Lysaker, Norway, 2009, 24 pp.

7. Standard Norge: "Testing hardened concrete - Tensile strength of test specimens". Part 6, NS-EN 12390-6:2009, Lysaker, Norway, 2009, 16 pp.

8. Skjølsvold O, Bakken N \& Johansen E : "Bestemmelse av E-modul iht NS3676 Losenhausen 5000kN trykkpresse". Betong og natursteinslaboratooriene, KS 14-05-04 122, SINTEF Byggforsk, Trondheim, Norge, 2007. (in Norwegian)

9. Standard Norge: "Concrete testing - Hardened concrete - Modules of elasticity in compression". NS 3676, Norway, 1987, 20 pp.

10. Hillerborg A: "The theoretical basis of a method to determine the fracture energy GF of concrete". RILEM Technical Committees, Materials and Structures, Vol. 18, Issue 4 2005, pp. 291-296.

11. Carolina Stalite Company: "Benefits of using Stalite". North Carolina, USA, accessed October 21. 2009. http://www.stalite.com/why-use-stalite.php?cat=138.html.

12. American Concrete Institute: "Guide for structural lightweight aggregate concrete". ACI213R-03, Farmington Hills, MI, United States, 2003, 38 pp.

13. Savija B, Lukovic M, Kotteman G, Chaves F S, de Mendoca Filho F F \& Schlangen E: "Development of ductile cementitious composites incorporating microencapsulated phase change materials". International Journal of Advances in Engineering Sciences and Applied Mathematics, Vol. 9, Issue 3, 2017, pp. 169-180.

14. Kuraray Co: "Characteristics of KURALON (PVA fibres), PVA fibres-application". Japan, available: http://kuralon-frc.kuraray.com/product-application

15. Standard Norge: "Testing hardened concrete - Density of hardened concrete". Part 7, 
Nordic Concrete Research - Publ. No. NCR 60 - ISSUE 1 / 2019 - Article 4, pp. 51-66

NS-EN 12390-7:2009, Lysaker, Norway, 2009, 16 pp.

16. European Union - Brite EuRam III: "Methods for Testing Fresh Lightweight Aggregate Concrete". BE96-3942/R4, December1999, 51 pp.

17. McCormick N \& Lord J: "Digital Image Correlation for Structural Measurements". ICE institution, Civil Engineering, 165 (CE4), 2012, pp. 185-190.

18. SINTEF procedure:"Fracture energy of prisms with notch in three point bending test". KS14-05-04123, September 2007, 3pp.

19. European committee for standardization: "Eurocode 2: Design of concrete structures General rules and rules for buildings". Part 1-1, EN 1992-1-1 (2004), 2004, 225 pp. 